\title{
Governing in nested institutions: environmental policy in the European Union and the case of packaging waste
}

\section{Thomas Gehring}

\begin{abstract}
The environmental policy of the European Community is nested within a broader institution devoted predominantly to market integration. It also co-exists with the domestic environmental policies of the member states. This institutional arrangement has important consequences for environmental governance in the present Union. Not only does the wide scope for domestic environmental action generate different logics of harmonization for the regulation of products and processes, it also creates an institutional preference for European product standards because this type of regulation allows a trade-off between environmental and single market concerns. This effect is demonstrated by the devclopment of the originally purely environmentally motivated and processrelated directive on packaging and packaging wastc adopted in 1994. During its preparation, this legislative project was supplemented with a strong product-related component that made a trade-off between policies possible and facilitated majority support in the Council.
\end{abstract}

KEY WORDS European environmental policy; institutional framework; internal market policy; packaging waste; process standards; product standards.

\section{INTRODUCTION}

Pursuing different policies in parallel within a comprehensive institutional framework does not preclude that a genuine environmental policy reaching far beyond an appendix of single market policy emerges, but it may be expected to affect outcomes. Moreover, policy-making at the European level does not replace the unilateral environmental policies of the member states; it merely supplements them. Hence, European environmental policy is subject to a horizontal tension among different policies pursued at the European level and a vertical tension between the levels of policy-making. It is most heavily influenced, however, by the cross-level and cross-policy conflict between domestically enacted environmental standards that undermine market integration and European single market policy.

Although awareness of the relevance of the institutional framework for the understanding of European policy-making is growing (Tsebelis 1994; Peters 1995), environmental policy analyses are still largely actor-oriented. They tend to focus on 
the struggle among various types of actor, for example member states, interest groups, or institutionally created actors like the Commission or the European Parliament (Héritier et al. 1994; Golub 1996). Implicitly or explicitly, these approaches take sides within the debate between intergovernmentalism (Moravcsik 1993) and neo-functionalism (Sbragia 1992; Sandholtz 1992) on the most suitable theoretical framework for an analysis of the European Community (now Union). Yet, it is the still largely under-explored (Caporaso and Keeler 1995: 49-51) institutional framework establishing supranational actors and providing subnational actors with opportunities for intervention that supports the decisionmaking system and relates otherwise unrelated decision processes to each other (Gehring 1996).

This article explores the institutional framework within which the participating actors pursue their interests in European environmental policy-making. In its first part, two key factors determining the logics of harmonization in the Community are identified, namely a) the co-existence of European environmental policy with European single market policy and with domestic environmental policy and b) the particular, institutionally established delimitation between the latter policies. These factors create an economically and environmentally motivated institutional preference for product regulation over process regulation. In the second part of the article, the impact of the European Community institutional framework on the European policy on packaging waste is explored. This policy culminated in the adoption of the heavily disputed directive on packaging and packaging waste in 1994 that is rooted in European environmental policy as well as in the lasting endeavour to protect the single market from adverse effects of domestic environmental action. This double basis enabled interested actors to supplement the originally envisaged process regulation with a product-related component and move the thrust of the project toward product regulation. Despite the sharp conceptional distinction between product and process regulation, a project does not always clearly fall into one of these categories. Manocuvring contributes to creating a highly complex outcome and implicitly transfers a wide margin of decisionmaking from the cumbersome Council negotiation system to other co-ordinating mechanisms within the Community system.

\section{NESTING ENVIRONMENTAL POLICY WITHIN A LARGER INSTITUTIONAL FRAMEWORK}

\subsection{Environmental policy in an economic integration organization}

The core of the European Union is undoubtedly formed by the three original communities, in particular the expansive European Economic Community (now: European Community, EC) founded by the member states to establish and maintain a common market for goods, services, capital and labour, and more recently supplemented by the single market programme and the monetary union project. Without this economic core the Community would remain a torso. Market integration has always been the centre of European integration. The EC as the governance institution established to achieve this task would not be capable of 
assisting the member states without developing mechanisms and selection criteria (Gehring 1994: 438-43) that privilege options promoting the internal market. Therefore, Community policy focuses primarily on harmonizing national laws that pose obstacles to trade (Taylor 1983).

However, the Community is no longer limited to market integration. Over time, several separate 'flanking policies' have evolved, among them environmental policy (Hildebrand 1992). Identified in the early 1970s as a new area of Community activity, European environmental policy has created numerous acts of environmental legislation (Rehbinder and Stewart 1985; Johnson and Corcelle 1989; Haigh 1992). From the outset, this new area of policy-making was supported by its own organizational apparatus, composed of a separate unit within the Commission that became a Directorate-General in 1981, a specific committee of the European Parliament and a council of environmental ministers. Substantively, the new policy relied on its own regularly revised programmes. Already the first programme (OJ C (73) 112) made abundantly clear that environmental policy had its own goals and was not at all to be understood as an appendix to the Community's internal market policy. Hence, from an institution primarily devoted to economic integration, an institutionally separate, substantively independent and organizationally distinct part emerged that, other things being equal, would favour a high standard of environmental protection.

Nesting different policies in a larger institution creates the risk of conflict. However, the selection criteria of the two policies do not necessarily contradict each other. Environmental policy measures may support market integration and remove trade barriers, and single market policy may contribute to raising environmental standards. In fact, prior to the introduction of specific competences over environmental issues into the EEC Treaty in 1987, European environmental policy was almost exclusively conducted in the name of market-related harmonization of national laws (Rehbinder and Stewart 1985).

Another aspect to be taken into account is that the emergence of European environmental policy does not hinder the member states from pursuing their own policy to protect the environment. The behaviour of citizens and economic actors in the Union's territory is governed by European environmental regulation as well as domestic legislation in a particular form of 'multi-level governance' (Marks et al. 1995; Jachtenfuchs and Kohler-Koch 1996). Hence, environmental regulation in the Union does not necessarily come about in the form of harmonized European standards. Frequently, progressive domestic action even provides models and precedents that are taken up later at the European level (Héritier et al. 1994; Héritier 1996). The parallel existence of (at least) two levels of environmental governance may cause a vertical, subsidiarity-type tension that centres around the distribution of regulatory competences between levels. However, despite different approaches adopted by the member states and varying degrees of regulatory depth, unilaterally adopted environmental action and European standards will generally intervene to raise the level of protection. Like the horizontal tension among policies at the European level, the vertical tension between the levels of policy-making does not necessarily create conflict.

However, as illustrated in Figure 1, European environmental policy is seriously 


\begin{tabular}{l|c|c} 
Policy & $\begin{array}{c}\text { Environmental } \\
\text { policy }\end{array}$ & $\begin{array}{c}\text { Single market } \\
\text { policy }\end{array}$ \\
\hline European Union & $\begin{array}{c}\text { European } \\
\text { environmental policy }\end{array}$ \\
\hline Member states & $\vdots$ \\
Domestic \\
environmental policy
\end{tabular}

Figure 1 Nesting of European environmental policy

affected by a third type of tension, i.e. between domestic environmental action and European single market policy. Domestic environmental policy establishes country-specific standards despite their possibly adverse effects on trade. Yet, single market policy is directed at removing national legislation posing barriers to trade. The former of these policies is regulative, while the latter is essentially deregulative. Therefore, these policies may be diametrically opposed to each other.

This conflict suggests a closer consideration of the conditions under which domestic environmental action threatens to contradict European single market policy (Weinstock 1984; Scharpf 1996). Process-related standards, e.g. emission standards for power stations or measures to protect habitats of wild animals, generally do not interfere with trans-boundary trade. If domestically enacted, they may require investment in abatement technology or restrict the exploitation of farmland and thus reduce the competitiveness of domestic producers, but they do not constitute obstacles to the exchange of goods and services in the internal market.

In contrast, unilaterally enacted product standards prohibit the marketing of products that do not fulfil the required conditions. Regularly, they disfavour imported goods and put the burden of adaptation on foreign producers. If a member state requires cars to be fitted with catalytic converters, it automatically excludes cars without such fittings from its market. Hence, it is product-related environmental regulation that creates the conflict between the collective intention of the member states to integrate their markets and their desire to protect their environment by domestic policy-making. This type of 'federal' tension stems from the close interrelationship of two policies and two levels of policy-making within a single institutional framework. It distinguishes European environmental policymaking from policy-making both in the traditional nation state and in the international system.

\subsection{Domestic environmental action in the single market}

The fundamental conflict between domestic environmental policy and European single market policy raises two interrelated questions. How far does the existence of 
the single market limit options for domestic environment action even in the absence of harmonizing secondary European legislation, and how far can the member states still pursue their own environmental policies even if they thwart European single market policy?

The EC Treaty does not address process-related domestic environmental policymaking (except for market-distorting taxation and subsidies) because this policy does not usually affect the operation of the single market. However, it addresses product regulation by prohibiting import quotas and 'all measures having equivalent effect' (Art. 30). The European Court of Justice (ECJ) interprets this clause extensively and considers 'all trading rules enacted by Member States which are capable of hindering, directly or indirectly, actually or potentially, intraCommunity trade ... as measures having an effect equivalent to quantitative restrictions' (C 8/74 [Dassonville], ECR 1974: 837). However, in Art. 36 the Treaty provides for a number of exceptions regarding measures inter alia 'justified on grounds of ... the protection of health and life of humans, animals and plants'. Hence, domestically enacted product standards are generally prohibited, but under certain circumstances they are justified in spite of their detrimental effect on the single market (Geradin 1993: 153-5; Krämer 1993).

The institutionalized standard for the appraisal of product-related national measures is thus composed of two elements that need to be balanced on a caseby-case basis. The Community assigns the final decision of such cases to the ECJ (Weiler 1991; Burley and Mattli 1993). Beginning in the 1970s, the Court declared, in a series of decisions that gathered a considerable amount of public attention, numerous national legislative acts incompatible with European law. Of particular relevance were the decisions on the German requirement for a minimum content of alcohol in liquor (C 120/8 [Cassis de Dijon], ECR 1979: 649-75), the German prohibition to market beer not produced according to the 'purity requirement' (C 178/84, ECR 1987: 1227-77) and the Italian regulation on the ingredients of pasta (C 407/85, ECR 1988: 4233-83). All these decisions had a deregulative effect. They rendered national protective measures inapplicable without replacing them with any regulations at the European level. The 'Cassis de Dijon' jurisdiction (Alter and Meunier-Aitsahalia 1994) became the basis for the hypothesis that the scope for autonomous national action was increasingly limited by Court-driven 'negative integration' (Scharpf 1996: 126-8). However, in all these cases the responsible governments had not convincingly justified their legal measures. Had they been able to prove that a risk to, for example, human health existed, or that scientific uncertainty prevailed about such risk, they would have enjoyed a greater scope from which to choose their own level of protection (C 178/84 [German Beer], ECR 1987: 1273). In fact, the Cassis jurisdiction forces the member states to actively justify their domestically enacted product standards in light of the exceptions envisaged in the Treaty.

Drafted in the 1950s, Art. 36 of the EC Treaty recognizes measures to protect the health and life of humans, animals and plants as justified, but it does not address environmental protection as such. Both the Commission and the Court, however, consider environmental protection an important Community interest that warrants domestically enacted product standards. In two landmark decisions, the Court held 
that a Danish ban on beverage cans (C 302/86, ECR 1988: 4607-33) and a Wallonian prohibition of waste imports (C 2/90, ECR 1992: 4431-81) were justified for reasons of environmental protection despite their adverse effects on the internal market. The situation may be summarized as follows: 'A national measure to protect the environment is permissible to the extent that it is objectively capable of reaching the aim, that it is not discriminatory and that the desired objective cannot be attained by less restrictive measures' (Krämer 1995: 127). Despite Court-driven negative integration under the Cassis de Dijon jurisdiction, the member states enjoy an almost unlimited freedom to choose their own level of environmental protection as long as specific Community measures are absent. However, their measures will be appraised against their own environmental goals. Hence, the internal market as established by the EC Treaty and enforced by the Commission and the Court does not seriously hinder the member states from pursuing their own environmental policy.

\subsection{Harmonization to limit unilateral action}

The institutional choice to favour domestic environmental policy over European single market policy may be most welcome from an environmental point of view. Yet, it is awkward from a market integration perspective and it does not ensure that the member states actually engage in activities to protect their environment. European environmental policy is the institutional response to these shortcomings. Unlike negative integration of the Cassis de Dijon jurisdiction type, it replaces national measures with harmonized European standards. It forces the member states actively to take decisions and, at least partially, removes policy-making from the domestic level. Moreover, it is apt to reconcile single market policy and environmental policy while avoiding the pursuit of one goal at the expense of the other. To achicve these regulatory tasks, harmonization does not have to fully deprive the member states of their scope for independent action. In fact, European environmental legislation resorted to a number of different forms of partial harmonization (Rehbinder and Stewart 1985:7-9) to reduce the degree of consensus required and to accelerate the pace of decision-making. Nevertheless, it is harmonization, not the existence of the internal market, that limits the freedom for national environmental policy-making. However, product regulation and process regulation follow quite different logics and are driven by different factors.

\subsubsection{Product-related harmonization}

The setting of European environmental product standards must be primarily designed to readjust the balance between domestic environmental policy and European single market policy. This balance will be restored if products meeting harmonized standards can be freely traded and marketed throughout the Community. The logic of single market policy demands that product-related harmonization establishes maximum standards and predominantly limits the freedom of action of countries with high standards. After all, high domestic standards exclude products from a domestic market even if they are produced in accordance with the 
laws of the producer country, while low domestic standards do comparatively little harm to trade. The logic of environmental protection is quite the reverse. Environmental deterioration is the consequence of low standards. Environmental product regulation must primarily address countries with low standards and limit their freedom of action. It will set comparatively high minimum standards while avoiding maximum standards that unnecessarily restrict the active environmental policy of the 'progressive' states. Accordingly, product-related European environmental regulation is governed by two diametrically opposed logics of harmonization. A solution for this collision is not provided for in the general rules of the institution. It will eventually have to be found case by case in the decision-making process that is still dominated by intergovernmental negotiations in the Council.

All the member states are interested in harmonized product standards that enable them to enjoy the advantages of the single market. After all, the market constitutes not only the core of the Community, it may also be assumed to constitute the main reason for joining the EC. Yet, the member states may have different preferences over the appropriate level of environmental protection envisaged by a harmonized standard. In game-theoretic terms, this constellation of interests reflects a 'Battle of the Sexes' situation (Scharpf 1996: 118-19). While generally not being prepared to reduce their existing standards, the high-standard countries may be inclined to sacrifice their option for future independent environmental policy-making in the regulated area to support market integration. They will not do so, however, unless the low-standard countries accept minimum standards at a level significantly above the 'lowest common denominator'. Thus, environmental product regulation involves a trade-off between the single market and environmental interests. It will come about in the form of minimum and maximum standards (i.e. either full harmonization or a corridor) at a considerable level of protection because high-level domestic regulation drives European product standards up.

A product standard harmonized in this way constitutes an almost optimal solution from a single market point of view, because it removes obstacles to trade in the internal market. The outcome is more ambiguous from an environmental perspective. It enhances the level of protection in the low-standard countries, but it also restricts the future development of domestic environmental policy by individual member states. Implicitly, harmonized product standards undermine the momentum driving European environmental standards up and raise the problem of 'obsolescence' (Rehbinder and Stewart 1985: 279). Over time, they may create a situation in which the member states have already sacrificed their competence to regulate a subject unilaterally while the Community system is (still) unable to respond effectively to demands of environmental protection owing to high consensus requirements. Harmonized product standards may thus lead right into the 'joint decision trap' (Scharpf 1985). The problem is illustrated by the long struggle over the introduction of catalytic converters for cars (Arp 1993) that took place in a subject area already harmonized by an earlier directive at a low level of environmental protection.

The single market Article, 100a, introduced into the EC Treaty in 1987 reflects the harmonization logic of product standards. It does not legally require the setting 
of maximum standards, but it suggests that maximum or full harmonization will be the normal case. It commits the Commission to a high level of environmental protection and includes an opening clause that allows member states to maintain, under certain conditions, existing domestic environmental regulation above the harmonized European standard. Owing to deliberately ambiguous wording, it is not entirely clear whether this clause also enables them to introduce unilateral measures after a harmonization directive has entered into force. No member state has ever attempted to do so. Since the opening clause is altogether very rarely used (Krämer 1995: 106-7) and the Court has further tightened the conditions for its application (C 41/93 [PCP] ECR 1994: I-1829-52), it does not seem to have the effect of actually encouraging continued environmental progress.

Hence, the institutional acceptance of unilaterally enacted environmental product standards in the absence of specific European legislation enables the member states to harmonize these standards at a comparatively high level of environmental protection. Yet, harmonization of a subject area undermines the force driving standards up. However motivated their adoption is, the logic of harmonization turns product standards predominantly into measures of single market policy.

\subsubsection{Process-related harmonization}

In contrast to product regulation, process standards are not affected by the triangular relationship among policies and levels because their harmonization is not a major point of concern for single market policy. They are largely dominated by the tension between European and domestic environmental policy. However, there are two exceptions to this rule (Stewart 1995). First, a country may gain competitive advantages by externalizing environmental costs, for example, by polluting international rivers and seas or by causing trans-boundary air pollution. Second, the desire of member states to create or uphold competitive advantages for their industries may lead to a 'race to the bottom' or a 'stalemate at the bottom'. Member states may be inclined to successively lower their standards to reinforce their competitive advantage only to find themselves collectively trapped in a vicious circle. Probably more important in the field of environmental protection, they may refrain from individually introducing a measure for fear of a competitive disadvantage. In these cases the market mechanism fails and single market policy may require harmonization. Distortions of this type are caused by low-standard countries. Accordingly, European single market policy rcquires minimum standards for process regulation. In contrast to product regulation, additional maximum standards would not contribute at all to solving the problem at stake. European environmental policy also focuses on raising the level of protection in countries with low standards by introducing European minimum requirements. However, all environmentally problematic subject areas are generally suited for European environmental regulation irrespective of their relevance for single market policy.

Again, the level of protection must be determined largely by the member states in the Council. High-standard countries may be assumed generally to favour harmonization at a comparatively high level of protection that both improves the state 
of the environment and contributes to reducing the competitive advantage of the low-standard countries. European process standards hardly restrict their options for independent action because they usually exceed harmonized minimum standards. In contrast, low-standard member states, i.e. the intended addressees of harmonization, may be expected to prefer no or very low European standards that do not threaten their competitive advantage, or overly limit their freedom of unilateral action. Except for the 'race to the bottom' case, in which all countries have 'mixed motives' and a collective incentive to compromise, there is no real incentive for the low-standard countries to reach agreement. This does not mean that process regulation is altogether impossible to achieve in negotiation systems (Héritier et al. 1994). Yet, it may be expected to be usually more difficult to agree upon than product regulation (Rehbinder and Stewart 1985: 9-11; Scharpf 1996: 119-21) and, therefore, remain at a comparatively low level. Hence, attempts to improve the state of the environment by European process standards will frequently end in 'structural subsidiarity', i.e. in the de facto re-transfer of the regulatory competence to the member state level, caused by the inability of the Council to reach substantive decisions. Environmental process regulation within the $\mathrm{EC}$ may be expected to resemble international environmental policy-making more closely than product regulation.

From a normative point of view this finding may be disappointing (Rehbinder and Stewart 1985). However, the reduced ability of the Community system to set process standards does not cause a regulatory gap as long as the member states retain their own regulatory capacity. In the 'multi-level governance system' of the present Union, regulation does not necessarily have to be decided upon at the European level. The member states may well exercise their regulatory autonomy as far as possible while empowering the Community (only) where necessary (Scharpf 1993). Therefore, the current challenge of harmonized environmental process regulation on subsidiarity grounds is not itself problematic, but the occurrence of 'structural subsidiarity' creates difficulties in the two types of situation mentioned in which the member states have already lost their individual regulatory capacity and depend on European regulation (Scharpf 1996).

The environmental competence of Art. $130 \mathrm{r}-\mathrm{t}$, introduced into the EC Treaty in 1987 , clearly reflects the logic of process harmonization. It is exclusively directed at setting minimum standards and ensures that member states are not hindered from enacting standards higher than those adopted under this competence (Art. $130 \mathrm{t}$ ). Therefore, it is not at all suited for product regulation. Moreover, the EC Treaty stipulates specifically that the harmonization of process standards at the European level is subject to the subsidiarity principle (Art. $130 \mathrm{r}$ ). Hence, it is recognized that process regulation may be dealt with at both the European and the member state level and implied that there must be at least some justification for setring European standards.

\subsubsection{Institutionalized preference for the harmonization of product standards over the regulation of processes}

The institutional arrangement creates a peculiar tension between domestic environmental policy and European single market policy that influences both the 
demand and the opportunities for active European environmental policy-making. Single market policy devoted to the removal of trade barriers focuses almost exclusively on the harmonization of product standards at any suitable level of environmental protection, while process regulation is of little relevance. However, European environmental policy may also favour product regulation over process regulation because the former promises substantive improvement in the low-standard countries and a continuing high level of protection in the progressive member states. In contrast, substantive process regulation is generally difficult to achieve and always threatened with being trapped in a 'structural subsidiarity'. Accordingly, the Commission as a corporate actor pursuing European single market policy and European environmental policy simultaneously has every reason to prefer the setting of product standards over process standards when designing the outline of a legislative project.

\section{EUROPEAN ENVIRONMENTAL POLICY IN PRACTICE: THE DIRECTIVE ON PACKAGING AND PACKAGING WASTE}

The recently adopted directive on packaging and packaging waste reflects the Commission's lasting intention to establish a European policy on packaging waste and its constant endeavour to protect the single market from adverse effects of unilateral environmental action. It demonstrates the impact of the nesting of European environmental policy within an institution that is primarily concerned with market integration.

\subsection{The context: European packaging waste policy and the struggle over Danish bottles}

The Commission began to prepare the proposal for a directive on containers of liquids for human consumption in 1975 . The project was initially directed at promoting the use of refill packaging and stirred up vigorous protest within interested industries. After several years of preparation, the Commission presented an entirely process-oriented and environmentally motivated proposal (COM (81) 1987 final) that did not refer at all to the possible single market implications of packaging waste policy and was based solely on the general enabling clause of the Treaty (Art. 235). The proposal merely established a European framework for the elaboration of narional packaging waste policies and obliged the member states to develop annual programmes for reducing packaging in household waste and increasing the share of refillable and/or recyclable packaging. Hence, the Commission had given up the idea of a coherent and uniform European packaging waste policy. When the directive on containers of liquids for human consumption (85/339/EEC, OJ L (85) 176) was eventually adopted in 1985 , it could be conceived at best as the first step on the long way toward a Community policy on packaging waste (Johnson and Corcelle 1989: 179-80; Haigh 1992: 5.8).

The conflict between domestic environmental policy in the packaging waste sector and European internal market concerns had an equally long history. In 1977 Denmark prohibited the marketing of soft drinks in one-way bottles and cans. The 
regulation undoubtedly constituted a - generally prohibited - obstacle to trade. The Commission had not yet decided whether it considered it as a justified unilateral action to protect the environment or as a violation of the duty to avoid trade restrictions (OJ C (79) 214/5), when it was informed in 1980 that the marketing of beer and soft drinks in Denmark was henceforth allowed only in licensed refillable containers. The Commission received protests from beverage and packaging producers and trade groups located outside Denmark that were supported in particular by the United Kingdom. In 1984 it persuaded the Danish government to modify its regulation so as to allow foreign producers and importers to market beverages up to a fixed maximum quantity ( $3000 \mathrm{hl}$ per year) in non-licensed containers under the condition that they established their own deposit and collection system. Metal cans remained prohibited (C 302/86, ECR 1988: 4608-9).

Despite this partial success the Commission instituted an infringement procedure that reached the Court in 1986. The Commission was then forced to argue in favour of the protection of the internal market without being inconsistent with the Community's packaging waste policy under the brand new directive on containers of liquids for human consumption. While this directive did not positively oblige the member states to introduce or develop refill systems, it expressly encouraged them to do so even though refill systems implicitly privilege local producers and almost inevitably create obstacles to free trade. Accordingly, the Commission had to accept a comparatively wide margin of choice for the member states to develop their own packaging waste policy. It did not challenge the Danish mandatory deposit and refill system, the strict ban on metal cans and the qualitative restrictions on the exceptional marketing of imported beverages in one-way containers. The Commission considered the Danish measures applicable to foreign producers 'to be incompatible with the principle of free movement of goods solely because of the limitations as to quantity and duration which they impose' (C 302/86, ECR 1988: 4611; emphasis added). The Court entirely followed the Commission position (C 302/86, ECR 1988: 4607-33). The decision in the Danish bottles case is frequently seen as a rare exception from the general Cassis de Dijon jurisdiction (Koppen 1993: 140-1). It effectively shelters national environmental measures in areas that are not subject to European harmonization legislation against the threat of Court-driven deregulation. Thus, it has the effect of forcing the Community to promote harmonization in order to contain the now almost unlimited freedom of domestic environmental action and to re-adjust the balance in favour of the single market gradually.

The restrictive effect of the judgment on the control of unilaterally adopted domestic action became apparent when Germany announced its packaging waste ordinance in 1990. The regulation reached far beyond any existing European approach to packaging waste and applied to all primary, secondary and transport packaging. It intended to stabilize existing refill systems and introduced a mandatory deposit on one-way packaging for beverages, detergents and paints as well as the general obligation of retailers to recycle packaging. Alternatively, producers and retailers could establish nationwide a separate collection system for packaging waste (the later 'green dot system'). Again, the Commission received complaints from interested industries based outside Germany. Although it 
scrutinized the system as to its conformity with the single market and entered into deliberations with the German government (Com (92) 278 final), it did not institure a formal infringement procedure. The German regulation and a parallel Dutch arrangement made clear that problems of this type would proliferate in the future.

Hence, a new project for establishing a harmonized European packaging waste policy could be linked to single market policy. In this case, it might be expected to create product standards and ensure the free circulation of packaging that meets these standards. It could also be designed to launch a fresh initiative for an environmental European packaging waste policy that would have to incorporate programmes to contain the amount of packaging waste and handle it in an environmentally sound manner. This approach could be expected to be more processoriented.

\subsection{Preparation of the directive}

\subsubsection{The first stage: an environmental and process-oriented project}

The German and Dutch regulations had an immediate impact on the European packaging waste policy. Prior to their announcement, the Commission followed a selective approach toward packaging waste and was preparing proposals on plastic waste and metal packaging (SEC (89) 934 final). Yet, in 1990 the DirectorateGeneral of the Environment (DG XI) started preparations for a directive addressing all packaging waste. The first 'Outline Proposal' (April 1991) envisaged three basic measures. First, the member countries should ensure that the amount of packaging waste per person does not exceed the EC average. This duty would have required a serious reduction by the wealthy northern member states with a high consumption of packaging. Second, the member states should ensure that within five years at least 60 per cent of packaging waste is recycled and another 30 per cent incinerated with energy recovery, while no more than 10 per cent is disposed of untreated. According to the Commission these targets amounted to a threefold increase in the share of recycled packaging. Third, member states should ensure that marketed packaging does not exceed certain limits as to the content of heavy metals and other dangerous substances.

All these duties, including the proposed product standards, came about in the form of minimum standards designed to enhance the level of environmental protection. The original Commission proposal envisaged an exclusively environmental project and focused primarily on process regulation. It would have a positive impact on the single market only if the member states implemented the harmonized European approach and voluntarily refrained from adopting additional measures on packaging waste.

Despite the protest of numerous interest groups, DG XI kept its environmental approach. The first comprehensive text for the operative part of the directive (Draft No. 1) retained the main duties of the Outline, but added some auxiliary obligations derived from the Danish bottles case judgment, including the duty to observe the proportionality of restrictions caused by implementing measures. In this form the draft proposal was discussed by the chefs des cabinets. This steering body, 
immediately below the College of Commissioners, requested that the ambitious environmental project be thoroughly revised in collaboration with other DGs, especially the directorate responsible for single market affairs (DG III).

Subsequently, the process standards of the proposal underwent some important changes. The Commission dropped the heavily criticized ceiling on the amount of packaging waste per capita for conceptional and political reasons (COM (92) 287 final). This obligation would have had the undesired effect of favouring comparatively light composite and plastic packaging over heavier materials (glass) even though it was more difficult to recycle. Countries exceeding the European per capita average of packaging waste might also have been forced to promote refill systems - a consequence that stirred vigorous political resistance and seemed, moreover, difficult to justify by 'life cycle analyses' of different types of packaging (Porter 1995). Accordingly, the recycling requirements became more important within the project. The originally envisaged, ambitious figures were retained throughout the preparation process. However, the obligation was somewhat relaxed by an extension of the transitory period from five to ten years and the introduction of a set of intermediate goals. It was also tightened by applying the recycling targets not only to packaging waste at large but also to separate classes of material, thus preventing a country from meeting its obligations by merely recycling the comparatively easily recyclable heavy fraction (glass and metal) while incinerating plastics and composite packaging.

All together, these modifications slightly weakened the proposal, but they largely responded to difficulties inherent in the regulated subject area and did not seem unreasonable. The proposal submitted by the Commission in autumn 1992 (OJ C (92) 263) still comprised environmentally ambitious targets. However, the original approach as developed during the intra-Commission preparatory process ran into the general difficulty of adopting process standards at a high level of protection in a negotiation system. It was not very probable that the member states would support the Europeanization of a packaging waste policy of this type.

\subsubsection{An additional product-related single market component}

The truly interesting development during the intra-Commission preparatory process was not related to the process standard dimension. Rather, it concerned the Commission's response to the fact that domestic packaging waste policies constantly undermined market integration without legally violating single market obligations. Starting late in 1991 the drafts began to address the single market aspect of packaging waste, but effective protection of the single market in the sector was not at all simple. Any express regulation of national implementation measures (Draft No. 3) would primarily restate the proportionality criteria developed by the Court and did not add anything new beyond specific notification procedures.

Therefore, the single market dimension as officially proposed came about in the form of a number of product standards, accompanied by the general obligation to accept that packaging meeting these standards be marketed throughout the internal market. The envisaged limits for the content of certain dangerous substances in packaging were supplemented by requirements for refillable and recyclable 
packaging. The member states were obliged to ensure that these standards were met (i.e. minimum standards), but they would also have the duty to accept on their markets packaging that fulfilled the European standards (i.e. de facto maximum standards for imported packaging). This additional product-related component effectively addressed the difficulties created by the Danish and German schemes that distorted the single market and de facto discriminated against foreign producers by actively promoting one type of packaging (e.g. refillable containers) over another, or by discouraging or even prohibiting certain types of packaging (e.g. beverage cans).

Hence, during the preparation phase within the Commission the project had moved considerably on the continuum between pure environmental policy and pure single market policy toward the latter. The proposal as officially submitted by the Commission was made up of two rather different components. It combined environmentally motivated process standards with product regulation predominantly motivated by single market concerns. The former provided the driving force for the entire project, but they were burdened with the difficulties inherent in harmonizing process regulation. The latter raised the resistance of environmentally progressive countries. In combination the two components increased the prospect of agreement on the whole package.

\subsection{The political decision process}

Appropriately based on the internal market competence (Art. 100 a), the directive was decided upon first under the collaboration procedure and later, after the entry into force of the Maastricht Treaty, by co-decision. Despite its extended rights under these procedures, the European Parliament did not exert much influence on the substance agreed upon (Golub 1996), while the Council considerably modified the proposal during the negotiations on its common position.

The newly introduced single market component remained virtually undisputed. Even the small group of environmentally concerned countries (Belgium, Denmark, Germany, the Netherlands) did not attempt to erase it from the directive. Moreover, these countries even accepted a significant downgrading of the requirements for recyclable and refillable packaging. However, they succeeded in introducing two new articles on waste prevention and on the promotion of refill systems that did not establish positive obligations but may have the effect of expanding opportunities for future domestic action. Implicitly, these provisions limit the impact of the single market component.

In contrast, the ambitious recycling goals proposed by the Commission were heavily disputed. They were vehemently supported by the group of environmentalist countries that had already established their own recycling systems and would be least affected by high European requirements. Not surprisingly, they were equally vigorously rejected by countries with a low standard in the sector (Greece, Ireland, Portugal, Spain, the United Kingdom). First, the Council postponed the decision on the long-term targets and agreed to determine figures only for an intermediate step to be reached within five years. For this step the Commission had proposed a minimum of 60 per cent recovery and 40 per cent 
recycling for each material of the total packaging waste. The Council lowered these figures considerably and settled for the duty to recover 50 per cent of the packaging waste, recycle 25 per cent of the total amount and (only) 15 per cent of each material. This compromise was further weakened by a temporary exemption for some lowstandard countries (Greece, Ireland, Portugal). As generally expected for process regulation, the targets agreed upon were hardly ambitious. That they were accepted at all may be attributed to their linkage with other parts of the directive.

This result would have constituted a case of 'structural subsidiarity' that would have retransferred most of the regulatory competence to the domestic level, if the member states had been allowed to go beyond these harmonized standards. However, several member states claimed that the German collection system undermined their own systems because it flooded their secondary raw materials markets with large quantities of glass and paper sold at low and occasionally even 'negative prices'. France, followed by other member states, threatened to close its borders to these imports (Agence Europe, 5-6 July 1993). The very success of the German system caused distortions of the internal market because subsidies of environmentally benign recycling resulted in economic difficulties. To solve this 'German problem', the Council supplemented the envisaged minimum goals with an environmentally entirely unsound cap limiting recovery to a maximum of $65 \mathrm{per}$ cent and recycling to 45 per cent of the total amount of packaging waste. Denmark, Germany and the Netherlands struggled hard, and eventually successfully, for an exemption that will allow exceeding the cap if a member state proves to have a sufficiently high capacity to process the waste collected. With these changes the directive on packaging and packaging waste $(94 / 62 / \mathrm{EG}, \mathrm{OJ} \mathrm{L}(94) 365)$ was adopted in December 1994.

In the course of the Council negotiations both groups of member states succeeded in watering down those components of the package by which they were particularly affected. The environmentally concerned minority reduced the impact of the single market component and, in the final stage, also of the cap provision. The majority lowered the recovery and recycling targets to a level that did not require serious adaptation of existing programmes in most member states. The impact of this outcome on the packaging waste policy in the member countries is still difficult to assess. At best, it may boost recycling interests and launch a positive feedback process that could lead to enhanced figures later on. However, the directive will almost certainly affect the scope for domestic packaging waste policies. It establishes a new, but highly complex and therefore unclear, institutional basis for future national action. Environmentally progressive countries attempting to use the exemption clause to break the cap provision on the recovery and recycling quota, or trying to protect existing legislation under the opening clause of Art. $100 \mathrm{a}$ (4), will have to meet still unclear conditions. Likewise, they may find the Commission, and eventually the Court, rejecting new measures in the packaging waste sector, such as a ban on PVC packaging, that most probably had been in conformity with European law prior to the adoption of the directive. Moreover, the new directive enables private parties to involve the ECJ via national courts. A producer or importer, believing himself to be adversely affected by the domestic packaging waste policy of a member state, may now choose an appropriate case and test 
whether the directive has modified the legal situation as compared to the status based upon the Danish bottles case jurisdiction.

Hence, the directive not only constitutes the - rather moderate - second step toward a European packaging waste policy. Within the framework of the European Community it will have an immediate impact on the single market policy and almost certainly affect the scope for future domestic action in the sector, even though the extent of this influence is not yet altogether clear.

\section{CONCLUSION}

European environmental policy emerges from an institution that is primarily devoted to economic integration and the establishment and maintenance of the internal market. It co-exists with other policies pursued in the same institutional framework, above all single market policy. It also co-exists with the domestic environmental policies of the member states. A policy decision adopted in one of these areas may generate undesired, and occasionally unexpected, consequences in other areas. The development of packaging waste policy in Europe illustrates this effect. Both domestic environmental action and European environmental policy interfered with single market policy and modified the context from which the 1994 directive emerged. While product standards may be assumed to be more closely intertwined with other policies than process standards, the directive on packaging and packaging waste demonstrates that legislative projects cannot always be clearly assigned to one of these categories. Since the substantive problem was rooted in different policies, the project could be deliberately transferred from (almost) pure process regulation into a mixture of process and product regulation. This step raised the probability of the adoption of the entire project, including its process component. As expected for product regulation, the member states bargained over the trade-off between single market aspects and environmental concerns. However, despite its process component the adoption of the packaging waste directive followed primarily the logic of product regulation.

To achieve majority support for the directive, the Council not only seriously watered down the individual parts of the package, it also added new elements that increased the complexity of the directive and created grey zones of unclear legislation. Sooner or later interested actors will attempt to exploit these grey zones. Conflicts will emerge and involve non-state actors, in particular the Commission and the Court as well as interested private parties instigating Court proceedings. Over time the initially broad margins for interpretation will be closed by secondary decisions, taking place, however, outside the Council negotiation system either in the form of bilateral negotiations, for example, between the Commission and a member state, or within the hierarchically organized judicial apparatus. In effect, the directive transfers a considerable part of collective decisions to be made to govern the sector from multilateral negotiations to other co-ordination mechanisms available within the institution, even though it does not specifically delegate these decisions to supranational actors. In this regard, the packaging waste policy also provides a lesson in governance within the multi-level system of the European Union. 
Address for correspondence: Thomas Gehring, Free University Berlin, Department of Political Science, Ihnestr. 22, D-14195 Berlin, Germany. Tel: +49 30 83846 24. Fax: +49308384160 .

\section{REFERENCES}

Alter, K.J. and Meunier-Aitsahalia, S. (1994) 'Judicial politics in the European Community: European integration and the pathbreaking Cassis de Dijon decision', Comparative Political Studies 26: 535-61.

Arp, H. (1993) 'Technical regulation and politics. The interplay between economic interests and environmental policy goals in the EC car emission legislation', in J.D. Lieffering, P. Lowe and A.P.J. Mol (cds), European Integration and Environmental Policy, London: Belhaven, pp. 150-71.

Burley, A.-M. and Mattli, W. (1993) 'Europe before the Court: a political theory of legal integration', International Organization 47: 41-76.

Caporaso, J.A. and Kecler, J.T.S. (1995) 'The European Community and regional integration theory', in C. Rhodes and S. Mazey (eds), The State of the European Union, Vol. 3: Building a European Polity?, Boulder: Lynne Rienner, pp. 29-62.

Gehring, T. (1994) Dynamic International Regimes. Institutions for International Environmental Governance, Frankfurt/M: Lang.

Gehring, T. (1996) 'Integrating integration theory: neofunctionalism and international regimes', Global Society 10: 225-53.

Geradin, D. (1993) 'Trade and environmental protection: Community harmonization and national environmental standards', Yearbook of European Law 13: 151-99.

Golub, J. (1996) 'State power and institutional influence in European integration: lessons from the Packaging Waste Directive', Journal of Common Market Studies 34: 313-39.

Haigh, N. (1992) EEC Environmental Policy and Britain, Harlow: Longman.

Héritier, A. (1996) 'The accommodation of diversity in European policy-making and its outcomes: regulatory policy as a patchwork', Journal of European Public Policy 3:14967.

Héritier, A., Mingers, S., Knill, C. and Becka, M. (1994) Die Veränderung von Staatlichkeit in Europa. Ein regulativer Wettbewerb: Deutschland, Großbritannien, Frankreich, Opladen: Leske \& Budrich.

Hildebrand, P.M. (1992) 'The European Community's environmental policy, 1957 to 1992: from incidental measures to an international regime?', Environmental Politics 1: 13-44.

Jachtenfuchs, M. and Kohler-Koch, B. (1996) 'Regieren im dynamischen Mehrebenensystem', in M. Jachtenfuchs and B. Kohler-Koch (eds), Europäische Integration, Opladen: Leske \& Budrich, pp. 15-44.

Johnson, S.P. and Corcelle, G. (1989) The Environmental Policy of the European Communities, London: Graham \& Trotman.

Koppen, I. (1993) 'The role of the European Court of Justice', in J.D. Lieffering, P. Lowe and A.P.J. Mol (eds), European Integration and Environmental Policy, London: Belhaven, Pp. 126-49.

Krämer, L. (1993) 'Environmental protection and Article 30 EEC Treaty', Common Market Law Review 30: 111-43.

Krämer, L. (1995) E.C. Treaty and Environmental Law, 2nd edn, London: Sweet \& Maxwell.

Marks, G., Hooghe, L. and Blank, K. (1995) European Integration and the State, Working Paper RSC 95/7, Florence: European University Institute.

Moravcsik, A. (1993) 'Preferences and power in the European Community: a liberal intergovernmentalist approach', Journal of Common Market Studies 31: 473-524.

Peters, B.G. (1995) 'Agenda-setting in the European Community', Journal of European Public Policy 1: 9-26.

Porter, M. (1995) 'Scientific uncertainty, the role of expertise and north-south variations in 


\section{T. Gehring}

the EU environmental process: the case of packaging and packaging waste', Zeitschrift für angewandte Umweltforschung 8: 516-31.

Rehbinder, E. and Stewart, R. (1985) 'Environmental protection policy', in M. Cappelletti, M. Secombe and J. Weiler (eds), Integration through Law. Europe and the American Federal Experience, Vol. 2, Berlin: de Gruyter.

Sandholtz, W. (1992) High-level Europe: The Politics of International Cooperation, Berkeley: University of California Press.

Sbragia, A.M. (1992) 'Thinking about the European future: the uses of comparison', in A.M. Sbragia (ed.), Europolitics: Institutions and Policymaking in the 'New' European Community, Washington, DC: Brookings, pp. 257-91.

Scharpf, F.W. (1985) 'Dic Politikverflechtungs-Falle: Europäische Integration and deutscher Föderalismus im Vergleich', Politische Vierteljabresschrift 26: 323-56.

Scharpf, F.W. (1993) Autonomieschonend and gemeinschaftsverträglich: Zur Logik der europäischen Mebrebenenpolitik, Discussion-Paper 93/9, Köln: Max-Planck-Institut für Gescllschaftsforschung.

Scharpf, F.W (1996) 'Politische Optionen im vollendeten Binnenmarkt', in M. Jachtenfuchs and B. Kohler-Koch (eds), Europäische Integration, Opladen: Leske \& Budrich, pp. $109-40$.

Stewart, R.B. (1995) Markets Versus Environment?, Jean Monnet Chair Papers 19, Florence: Robert Schuman Centre at the European University Institute.

Taylor, P. (1983) The Limits of European Integration, New York: Columbia University Press.

Tsebelis, G. (1994) 'The power of the European Parliament as a conditional agenda setter', American Political Science Review 88: 128-42.

Weiler, J.H.H. (1991) 'The transformation of Europe', Yale Law Journal 100: 2403-83.

Weinstock, U. (1984) 'Nur cine curopäische Umwelt? Europäische Umwcltpolitik im Spannungsfeld von ökologischer Vielfalt and ökonomischer Einheit', in E. Grabitz (ed.), Abgestufte Integration. Eine Alternative zum berkömmlichen Integrationskonzept?, Kehl/Rhein: Engel, pp. 301-44. 